\title{
The family's attitude towards addiction
}

\author{
Vasileios Kalampalikis \\ From $1^{\text {st }}$ International Congress on Neurobiology and Clinical Psychopharmacology and European \\ Psychiatric Association Conference on Treatment Guidance
}

Thessaloniki, Greece. 19-22 November 2009

We already know that addiction is a complicated phenomenon. One of the most important factor is family conditions. Try to write in short way, we could say that in one hand family is an important factor on the creation of substratum for dependence. On the other hand don't underestimate other factors of life such as personality, society and quality of life that are also very important. Family could take a serious role in the solution of addiction problem. Shortly, I will describe the basic steps of the way of a family that has one or more drug - addicted members.

- It takes a long time until family recognize the problem. Usually, family gives to the problematic behavior a lot of excuses.

- When they realize the problem fear, panic, perplexity, anger and sense of guilt comes to their lives

- Then a member of family (usually the mother) try to find the solution alone with many ways (doctors, lawyers, priests or Psychologists e.t.c) or try to press the drug - addicted person by saying "stop using drugs otherwise I will die or I will stop working to stay with you". This kind of family reaction can be continued for a long time

- All the practices of the family concern its' drug addicted member (s)

- Finally the last step, and of course the hard one, is when family focuses to the "real" meaning: they cannot help the addicted people rebuild their lives. But can avoid behaviors that encourage the drug - addicted to stay in the problem. Family can also take care of the needs of its other members

- Family recognizes that addiction is a human behavior and can happen to almost everyone, to every "kind" of family.

KETHEA ITHAKI Therapeutic Program, Thessaloniki, Greece
Published: 22 April 2010

doi:10.1186/1744-859X-9-S1-S19

Cite this article as: Kalampalikis: The family's attitude towards addiction. Annals of General Psychiatry 2010 9(Suppl 1):S19.
Submit your next manuscript to BioMed Central and take full advantage of:

- Convenient online submission

- Thorough peer review

- No space constraints or color figure charges

- Immediate publication on acceptance

- Inclusion in PubMed, CAS, Scopus and Google Scholar

- Research which is freely available for redistribution

Submit your manuscript at www.biomedcentral.com/submit
C Biomed Central 